Trends in Agriculture \& Life Sciences, Vol. 57, 2019. 12.

농업생명과학연구동향, 제 57 집

https://doi.org/10.29335/tals.2019.57.48

Short Communication

$$
\begin{gathered}
\text { 벼 출수기 이후 광합성이 등숙에 미치는 영향 } \\
\text { 문현동·조재일* }
\end{gathered}
$$

전남대학교 농업생명과학대학 응용식물학과

\title{
Effect of Leaves Photosynthesis after Heading Time on Rice Ripening Rate
}

\author{
Hyundong Moon and Jaeil Cho* \\ Department of Applied Plant Science, Chonnam National University \\ *Corresponding author: chojaeil@jun.ac.kr
}

\begin{abstract}
Rice ripening rate is one of important yield component. The contribution to ripening rate was tested by removing the leaves after heading time. In addition, the ripening characteristics under high temperature condition were investigated in temperature gradient field chamber (TGFC). The ripening rate was dropped from $95.3 \%$ to $16.9 \%$ by removing leaves after heading. It means that the photosynthesis of leaves after heading is most great contributor on rice ripening. However, under high temperature, rice ripening rate was increased by infertility, but the contribution of leaves photosynthesis after heading was decreased. This information will be helpful to understand rice yield in future climate condition.
\end{abstract}

Additional key words: Rice, Photosynthesis, Heading, Ripening

\section{서 론}

농업은 근본적으로 광합성을 통하여 태양에너지를 포획하는 체계이며, 작물의 수량은 광합성 체계의 규모 나 효율에 의존하고 있다( 1,2$)$. 작물은 초기 생장의 대 부분을 엽면적 확장에 투자함으로써 태양복사를 최대 로 포획하여 효율적으로 이용하는 전략을 취하며, 결국 작물의 건물생산은 생육기 동안 순 $\mathrm{CO}_{2}$ 동화작용의 축 적된 결과로 볼 수 있다. 이러한 작물 개체의 전체 건물 축적량을 생물학적 수량(biological yield)이라고 하며, 경제적으로나 농업적으로 가치가 있는 식물체 기관의 용적이나 무게를 경제적 수량(economic yield)이라고
별도로 지칭한다(2). 이와 관련하여 수확지수(Harvest index, 경제적 수량/생물학적 수량 $\times 100$ )는 농가 수익 증대에 이바지하는 작물의 광합성 산물 분배에 체계를 이해하는 지수로 널리 이용되고 있다.

우리나라 대표 식량 작물인 벼의 경제적 수량은 종 실의 무게로 나타낼 수 있다. 종실에 저장되는 광합성 산물은 일반적으로 잎의 광합성, 잎 이외 부위의 광합 성, 다른 식물기관에 저장된 광합성 산물의 재이동의 3개 주요 소스(source)로부터 기인한다(3). 이러한 3종 류 소스로부터의 종실 무게 기여 정도는 수확지수를 높 여 수량을 증대시키기 위해 보다 자세히 이해될 필요가 있다. 예를 들어 계절별 일사 조건에 최적으로 적응된 
각 작물 종의 엽면적지속시간(LAD, Leaf Area Duration) 은 기후변화로 인해 태양에너지 포획 효율 또한 달라질 수 있으므로 생육 시기별로 광합성의 종실 기여 정도가 파종 및 수확 시기와 신품종 육종 등을 위해 필요할 것 이다.

특히 출수기 전후로 나뉘는 영양생장기와 생식생장 기의 광합성 효율에는 큰 차이가 있으므로, 종실 기여 정도가 다양한 미래기후 조건에서 실험될 필요가 있다 (4). 따라서 본 실험에서는 온도구배야외챔버(TGFC, Temperature Gradient Field Chamber)를 이용하여 일반 기온과 그보다 $3^{\circ} \mathrm{C}$ 높은 온난화 조건에서 재배된 벼에 서 출수 이후 잎의 광합성이 종실 등숙에 미치는 영향 을 실험하였다.

\section{재료 및 방법}

\section{1. 온도구배야외챔버 및 벼 재배 조건}

본 실험은 전남대학교 용봉캠퍼스 농업실습교육원 논에 설치된 TGFC에서 2019년 5월 30일에 중묘를 이양하여 10 월 10 일 수확 때까지 수행되었다. 벼 품종 은 중만생종인 일미였으며 재식거리는 관행 농업인 $15 \times 30 \mathrm{~cm}$ 로 하였고, 1주(포기)에 3 4본을 재식하였다. 실험에 사용한 TGFC는 1 개였으며, 각 시설당 $43.2 \mathrm{~m}^{2}$ $(1.8 \times 24 \mathrm{~m})$ 의 면적에 960 주 $(12 \times 80$ 주 $)$ 의 벼를 재배하였 다. 비료는 시설 면적당 $\mathrm{N}$ (질소) $9 \mathrm{~kg}, \mathrm{P}$ (인) $4.5 \mathrm{~kg}$, $\mathrm{K}$ (칼륨) $5.7 \mathrm{~kg}$ 을 기준으로 처리하였으며, 밑거름과 분 얼거름을 $5: 2$ 비율로 분사하였다.

$\mathrm{TGFC}$ 는 입구가 막힘없이 개방되어 있어 안쪽은 항 시 환풍기를 작동시켜 공기가 입구에서 시설 안쪽으로 이동하여 환풍기를 통해 배출되도록 설계되었다(5). $\mathrm{TGFC}$ 의 입구는 외부 기온(AT, Ambient Temperature) 과 같고, 시설 가장 안쪽의 기온은 $\mathrm{AT}$ 지점보다 $3^{\circ} \mathrm{C}$ 높은 환경 $\left(\mathrm{AT}+3^{\circ} \mathrm{C}\right)$ 이 유지되도록 시스템이 작동된다.

\section{2. 벼의 잎 제거 실험}

$\mathrm{TGFC}$ 의 $\mathrm{AT}$ 와 $\mathrm{AT}+3^{\circ} \mathrm{C}$ 인 곳에서 재배하는 벼를 대 상으로 출수 직후에 모든 잎을 제거하였다. 이후 새롭 게 나오는 잎들도 계속 제거함으로써 수확 때까지 잎이 없는 상태를 유지했다. 수확 후에는 완전립과 불완전립 을 구분하여 등숙률을 구하고, 완전립을 대상으로 천립 중을 조사했다.

\section{결과 및 고찰}

\section{1. 출수 후 잎의 광합성과 등숙률}

Fig. 1 은 $\mathrm{AT}$ 와 $\mathrm{AT}+3^{\circ} \mathrm{C}$ 의 조건에서 정상적으로 재 배한 벼와 출수 직후 잎을 제거한 경우의 등숙률을 각 각 나타낸 것이다. AT에서 잎을 제거하지 않았을 때의 등숙률은 약 $95.3 \%$ 로서 우리나라 벼 품종 대부분의 등 숙률과 유사한 모습을 보였다. 하지만 AT에서 출수 후 잎을 제거한 경우의 등숙률은 $16.9 \%$ 로 급격히 감소하 였으며, 이것은 $\mathrm{AT}$ 의 벼와 비교해 $82 \%$ 가 감소한 결과 이다. 이는 출수 후 잎의 광합성이 종실 등숙에 약 $82 \%$ 정도로 크게 이바지한다고도 볼 수 있다. 나머지 $18 \%$ 는 출수 이전의 광합성 산물이 식물체 내에서 소비되지 않았다가 종실로 재이동된 것과 출수 후 잎 이외 부위 의 광합성의 합일 것으로 사료된다.

따라서 출수 전의 광합성 산물은 잎의 확장에 거의 소비되며, 출수 후에는 영양생장기 때 확장된 잎에서 생산되는 광합성 산물이 종실 등숙에 크게 이바지하는 것으로 보인다. 하지만, 잎은 일반적으로 출수 이후 엽 록소 함량이 점차 낮아짐에 따라 광합성 효율도 떨어진 다(6). 이것은 잎에서 생산되는 광합성 산물에 의해 종 실의 등숙이 진행될수록, 상대적으로 잎의 광합성 효율 은 떨어지는 제로섬(Zero-Sum)과 같은 모습이다 $(7,8)$. 결국, 높은 등숙률을 유지하기 위해서는 출수 전에 잎 을 최대한 확장하여 출수 후에 많은 광합성 산물을 생 산하는 것이 유리할 것으로 사료된다.

\section{2. 고온 조건과 등숙률}

고온 조건인 $\mathrm{AT}+3^{\circ} \mathrm{C}$ 에서는 등숙률이 $59.3 \%$ 가 되었

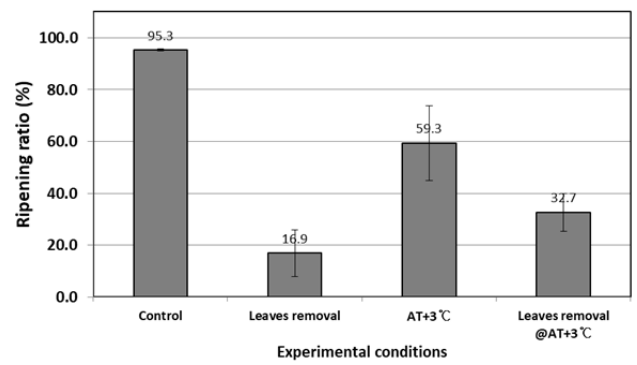

Fig. 1. Ripening ratio at four different experimental conditions by elevated air temperature and leaves removal after heading. 
는데, 이는 임계온도 이상의 환경에서 수정 저해에 따 른 불임이 원인인 것으로 추측된다(6). 일부 수정에 성 공한 경우에는 잎으로부터 광합성 산물을 공급받아 등 숙이 정상적으로 진행된 것으로 보인다. $\mathrm{AT}+3^{\circ} \mathrm{C}$ 에서 도 출수 후 잎을 제거하면 등숙률이 감소하였는데, 그 감소 정도가 약 $45 \%$ 로서 AT에서 출수 후 잎의 제거로 등숙률이 감소한 정도인 $82 \%$ 보다 작다.

이것은 $\mathrm{AT}+3^{\circ} \mathrm{C}$ 의 고온 조건에서 영양생장기 동안 빠르게 잎을 확장하였고, 출수기 차이는 크지 않았으므 로 엽면적지속시간이 증가하고 누적 광합성량이 많아 짐에 따라, 광합성 산물 재이동의 등숙 기여율이 증가 한 것으로 보인다. 이를 뒷받침하기 위해 생육기간 동 안의 광합성을 정량적으로 측정하는 등의 상세한 실험 이 뒤따라야 할 것이다.

\section{3. 천립중}

$\mathrm{AT}$ 에서 재배한 일반적인 경우의 천립중은 $24.4 \mathrm{~g}$ 으 로서 알려진 일미벼 품종의 천립중과 유사하였다. 또 한, 이는 출수 후 잎을 제거한 경우와도 크게 다르지 않았다(Fig. 2). 이러한 모습은 등숙률의 경우와는 다른 모습이다. 이것은 등숙의 기계적 메커니즘이 이삭의 모 든 종실을 대상으로 광합성 산물로 동시에 채우는 방식 이 아니라, 종실 하나씩 차례로 등숙을 완성해 나가는 것으로 사료된다. 이를 확인하기 위해 이삭 내 종실의 위치별로 등숙률을 확인하는 실험이 필요할 것이다.

\section{요 약}

온난화 조건에서 출수 후 광합성 산물이 벼의 등숙 률에 이바지하는 정도를 조사하였다. 출수 후 잎을 제

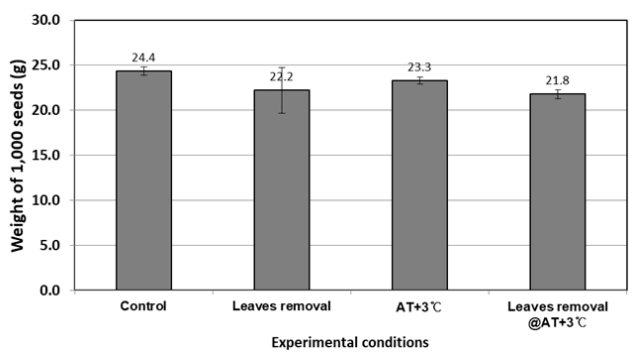

Fig. 2. Weight of 1,000 seeds at four different experimental conditions by elevated air temperature and leaves removal after heading.
거하여 광합성을 못하는 벼의 경우 등숙률이 $82 \%$ 감소 하였다. 하지만, $3^{\circ} \mathrm{C}$ 가 높은 온난화 조건에서의 감소 폭 은 $45 \%$ 로 작아졌다. 이는 높은 기온에서 재배된 벼의 엽면적지속시간이 길어졌기 때문으로 보인다. 반면, 천 립중은 온난화 및 출수 후 잎의 제거의 영향에 따라 거 의 차이가 없는 것으로 보아 등숙의 기계적 메커니즘은 이삭의 각 종실에 광합성 산물을 차례로 채워 나가는 형태일 것으로 사료된다. 이를 명확히 하기 위해 추가 의 정밀한 실험이 요구된다.

\section{감사의 글}

이 논문은 2016년도 정부(교육부)의 재원으로 한국 연구재단의 지원을 받아 수행된 기초연구사업(과제번 호: NRF-2016R1D1A1B03933218)입니다. 또한, 실험을 도와준 강지수, 김민서, 김민영, 김수지, 김주희, 박건, 박현지, 서강해, 서재서, 이수인, 이현지, 장지원, 정유 현, 조민영, 조은이, 최우혁에게 감사의 뜻을 표합니다.

\section{참고문헌}

1. Shibles, R. M. and Weber, C. R. 1965. Leaf area, solar radiation interception and dry matter production by soybeans. Crop Sci. 5: 575-578.

2. Sinclair, T. R. 1998. Historical changes in harvest index and crop nitrogen accumulation. Crop Sci. 38: 638-643.

3. Marshall, C. and Wardlaw, I. F. 1973. A comparative study of the distribution and speed of movement of $14 \mathrm{C}$ assimilates for foliar applied 32P-labelled phosphate in wheat. Aust. J. Biol. Sci. 23: 1-13.

4. Kim, J., Shon, J., Lee, C., Yang, W., Yoon, Y., Yang, W., Kim, Y. J. and Lee, B. 2011. Relationship between grain filling duration and leaf senescence of temperate rice under high temperature. Field Crops Research. 122: 207-213.

5. Horie, T., Nakagawa, H., Nakano, J., Hamotani, K. and Kim, H. Y. 1995. Temperature gradient chambers for research on global environment change. III. A system designed for rice in Kyoto, Japan. Plant, Cell \& Environment. 18: 1064- 
1069.

6. Satake, T. and Yoshida, S. 1978. High temperature-induced sterility in indica rices at flowering. Japanese Journal of Crop Science. 47: 6-17.

7. Jung, W. S., Lee, K. J. and Lee, B. W. 2015. Responses of spikelet fertility to air, spikelet, and panicle temperatures and vapor pressure deficit in rice. Journal of Crop Science and
Biotechnology. 18: 209-218.

8. Maruyama, A., Weerakoon, W. M. W., Wakiyama, Y. and Ohba, K. 2013. Effects of increasing temperatures on spikelet fertility in different rice cultivars based on temperature gradient chamber experiments. Journal of Agronomy and Crop Science. 199:(6), 416-423. 